Article

\title{
Properties and Structure of Deposited Nanocrystalline Coatings in Relation to Selected Construction Materials Resistant to Abrasive Wear
}

\author{
Jacek Górka ${ }^{1, *(1)}$, Artur Czupryński ${ }^{1}$, Marcin Żuk ${ }^{1}$, Marcin Adamiak ${ }^{2}$ (D) and Adam Kopyść ${ }^{2}$ \\ 1 Department of Welding Engineering, Silesian University of Technology, Konarskiego 18A, \\ 44-100 Gliwice, Poland; artur.czuprynski@polsl.pl (A.C.); marcin.zuk@polsl.pl (M.Ż.) \\ 2 Institute of Engineering Materials and Biomaterials, Silesian University of Technology, Konarskiego 18A, \\ 44-100 Gliwice, Poland; marcin.adamiak@polsl.pl (M.A.); adam.kopysc@gmail.com (A.K.) \\ * Correspondence: jacek.gorka@polsl.pl; Tel.: +48-32-237-1445
}

Received: 6 June 2018; Accepted: 9 July 2018; Published: 10 July 2018

\begin{abstract}
Presented in this work are the properties and structure characteristics of MMA (Manual Metal Arc) deposited nanocrystalline coatings ( $\mathrm{Fe}-\mathrm{Cr}-\mathrm{Nb}-\mathrm{B}$ ) applied to an iron nanoalloy matrix on an $\mathrm{S} 355 \mathrm{~N}$ steel substrate in relation to selected construction materials resistant to abrasive wear currently used in industry. The obtained overlay welds were subjected to macro and microscopic metallographic examinations; grain size was determined by $X$-ray diffraction (XRD), and chemical composition of precipitates was determined by energy-dispersive $X$-ray spectroscopy (EDS) during scanning electron microscopy (SEM). The size of the crystalline grains of the $\mathrm{Fe}-\mathrm{Cr}-\mathrm{Nb}-\mathrm{B}$ nanocrystalline microstructure was analyzed using an Xpert PRO X-ray diffractometer. Analysis of the test results of the obtained layers of arc-welded Fe-Cr-Nb-B-type alloy confirmed that the obtained layers are made of crystallites with a size of $20 \mathrm{~nm}$, which classifies these layers as nanocrystalline. The obtained nanocrystalline coatings were assessed by hardness and with the use of metal-mineral abrasion testing. The results of the coatings' properties tests were compared to HARDOX 400 alloy steel.
\end{abstract}

Keywords: abrasive wear; nanocrystalline layers; abrasion resistant plate; deposit weld

\section{Introduction}

Wearing of machine parts poses an important problem in terms of scientific, technical and economic potential. In most cases, the mechanisms of wear are highly complex and include many interrelated factors whose impact depends on the environment and working conditions of the part in question. The variety of the types of wear modes leads to the specialization of materials used in the construction of parts subject to abrasive wear in order to ensure the highest resistance to wearing of surface layers under specific operating conditions. One of the types of such specialized materials is Abrasion Resistant (AR) plates [1-7]. The structure and properties of the surface layer are, to a large extent, the main factor when considering materials for machine parts in terms of durability. In recent years, there has been dynamic research in the development of new abrasion-resistant materials containing layers of unique properties and structures differing significantly from previous work. In particular, new approaches such as improved hardness, resistance to impact loads and low coefficients of friction are the main concerns when developing new materials [8-19]. The rapid development of nano-structurally modified materials is foreshadowing an increase in their application in novel welding technologies. The wide variety of properties inherent to nano-structually modified materials are a paradigm shift, bringing new possibilities through the use of nanomaterial-based surfacing technologies. Nanomaterials are classified as single or multiphase polycrystals characterized 
by a grain size on the order of $1 \times 10^{-9} \mathrm{~m}$ to $250 \times 10^{-9} \mathrm{~m}$ in diameter. At the upper limit of this range, the term "very fine" is used with respect to grain size on the order of 250-1000 nm in diameter [20-27]. Nanocrystalline materials are structurally characterized by a high volume fraction at the grain boundaries, which significantly changes their physical, chemical and mechanical properties in comparison to conventional coarse grains, whose grain size is usually on the order of 10-300 $\mu \mathrm{m}$. Until now, existing nanomaterials used for nanostructure coatings and layers have shown a significantly higher (many times) wear resistance compared to traditional steel alloy-based materials. Due to the high cost and continuous development of their production technology, nanostructural materials have not been widely applied [28-33].

\section{Experimental Section}

The purpose of the performed experiments was to compare the structure and properties of $\mathrm{Fe}-\mathrm{Cr}-\mathrm{Nb}-\mathrm{B}$ nanocrystalline surface layers deposited by manual metal arc (MMA) welding with a covered electrode $3.2 \mathrm{~mm}$ in diameter to previously used abrasion-resistant materials. HARDOX 400 steel was used as a reference material in the assessment of resistance to metal-mineral abrasion. The following materials were tested in the experiments:

(1) Nanocrystalline layer deposited with a covered electrode-NANO (Fe-Cr-Nb-B)

(2) Abrasion-resistant plate-ABRECOPLATE

(3) Abrasion-resistant plate-CDP

(4) Abrasion-resistant layer deposited by covered electrode-ABRADUR 64

(5) Abrasion-resistant layer deposited by GMA with a ceramo-metallic wire containing $50 \%$ WC (tungsten carbide)

(6) Abrasion-resistant sheet-HARDOX 400.

Metallographic examinations of the deposited coatings were carried out on a Zeiss SteREO Discovery, and LEICA MEF4A optical microscope (Leica Microsystems, Cambridge, UK) in addition to a Zeiss Supra 35 (SEM) scanning electron microscope (Carl Zeiss GmbH, Jena, Germany). Metallographic images were taken of transverse sections with respect to weld deposition direction. The specimens were prepared by standard metallographic techniques and etched in Nital solution. Phase compositions of the investigated materials in addition to the size of the crystallographic grains of nanocrystalline microstructure were determined using an Xpert PRO X-ray diffractometer with step data logging, employing the filtered K@ X-rays. The chemical composition of precipitates was determined by energy-dispersive X-ray spectroscopy (EDS) with an EDAX detector. Hardness tests were conducted on a Zwick Roell ZHR hardness tester based on the Rockwell method, while cross-sectional hardness was measured using the Vickers method with a Future-Tech FM-700 tester (Future-Tech Corp., Kawasaki, Kanagawa Prefecture, Japan).

\subsection{Nanocrystalline Layer Deposited with Covered Fe-Cr-Nb-B Electrode}

The Fe-Cr-Nb-B nanocrystalline layer, shown in Table 1, deposited by MMA with a $3.2 \mathrm{~mm}$ covered electrode on an S355N steel alloy substrate is shown in Figure 1. MMA deposit welding was performed with a constant direct current of $100 \mathrm{~A}$ in the flat position (PA). During welding, the electrode was set at an angle of $90^{\circ}$ with respect to the surface of the welding base. The sheet surface was ground and pre-heated with a gas torch to a temperature of $80^{\circ} \mathrm{C}$.

Table 1. Chemical composition and hardness of the tested deposit weld.

\begin{tabular}{cccccccc}
\hline \multicolumn{7}{c}{ Chemical Composition, wt \% } & \multirow{2}{*}{ HRC } \\
\cline { 1 - 7 } C & Cr & $\mathbf{B}$ & $\mathbf{N b}$ & $\mathbf{M n}$ & $\mathbf{S i}$ & Fe & \\
\hline 1.4 & 15.2 & 4.0 & 3.4 & 0.4 & 0.4 & remainder & $68-70$ \\
\hline
\end{tabular}




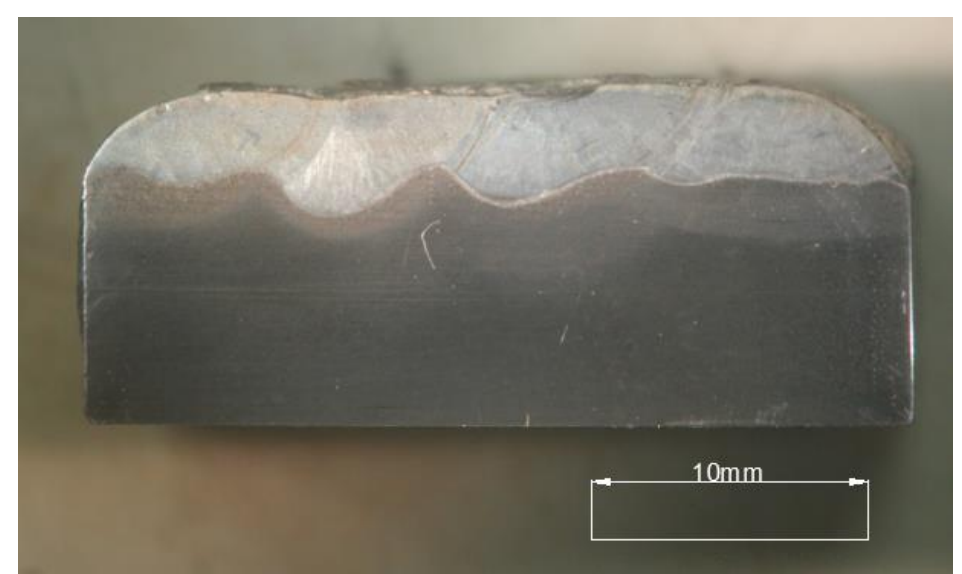

Figure 1. Macrostructure of the cross-section of a nanocrystalline layer, the average width of the overlay layer is $3 \mathrm{~mm}$.

According to the manufacturer's data, the Fe-Cr-Nb-B nanocrystalline alloy electrodes mostly consist of very hard boron carbide fractions evenly distributed in a semi-amorphous iron alloy matrix, yielding a hardness of $67-70$ HRC. The deposit weld should have a high abrasion resistance and an increased resistance to dynamic loads due to these characteristics. The electrodes can be used for both direct- and alternating-current welding.

\subsection{Abrasion Resistant Plate-ABRECOPLATE}

ABRECOPLATE abrasion-resistant materials are produced in the following formats: plates (straight or beveled, by special order), bars, buttons (in the shape of a dome, octagonal, protecting screws). ABRECOPLATE is a layered material composed of chromium-molybdenum white cast iron, metallurgically connected to a soft-structural steel underlying plate, as detailed in Table 2.

Table 2. Chemical composition and physical characteristics of the abrasion-resistant layer of ABRECOPLATE.

\begin{tabular}{ccccccc}
\hline \multicolumn{7}{c}{ Chemical Composition, wt \% } \\
\hline C & Cr & Mo & Mn & Si & Ni & Fe \\
\hline $2.8-3.6$ & $14.0-18.0$ & $2.3-3.5$ & $0.5-1.5$ & 1.0 max. & 5.0 max. & remainder \\
\hline \multicolumn{7}{c}{ Mechanical Properties } \\
\hline HRC & Heat Resistance $\left({ }^{\circ} \mathrm{C}\right)$ & Creep Resistance $\left({ }^{\circ} \mathrm{C}\right)$ \\
\hline 64 & 540 & 595 \\
\hline
\end{tabular}

ABRECOPLATE's high abrasion-resistance properties are due to the structure of the surface layer. The special heat treatment (hardening throughout) of cast iron allows for the obtainment of a microstructure consisting of chromium-molybdenum carbides in an almost completely martensitic matrix. The substrate of these abrasive plates is a soft-structural steel. Undercoated cast iron is joined by soldering with a soft copper-based binder which ensures adequate stress transfer, shown in Figure 2 .

An important advantage of ABRECOPLATE abrasive discs is the content of abrasive material in relation to the primer, which is 3:1. 


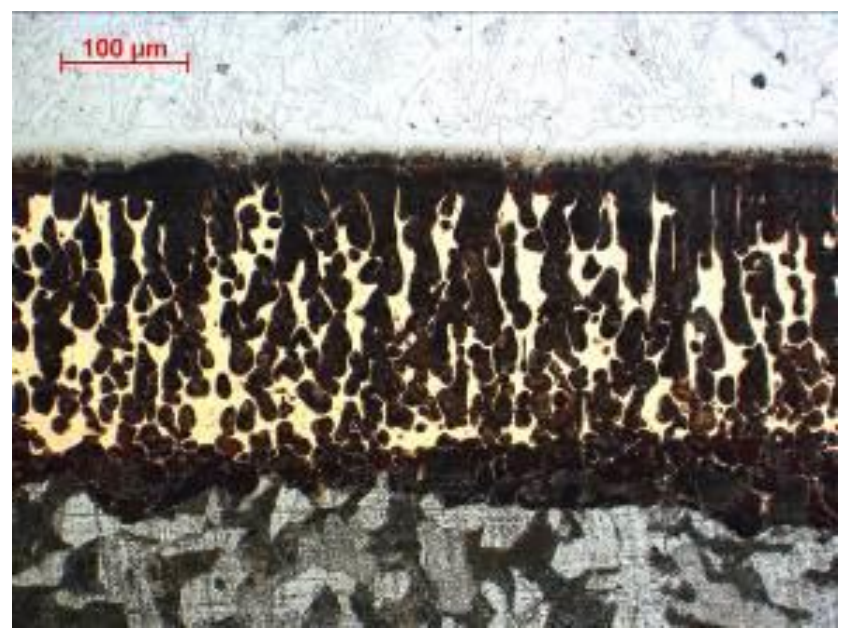

Figure 2. Microstructure of the intermediate layer of ABRECOPLATE cross-section.

\subsection{CDP Plate}

Abrasion-resistant plates are manufactured by welding a sheet of non-alloy, low-alloy or high-alloy steel with shielded powder wire or self-shielded wire, as shown in Table 3 and Figure 3.

Table 3. Chemical composition of the surface deposit weld.

\begin{tabular}{cccccccc}
\hline \multicolumn{7}{c}{ Chemical Composition, wt \% } & \multirow{2}{*}{ HRC } \\
\cline { 1 - 7 } C & $\mathbf{C r}$ & $\mathbf{B}$ & $\mathbf{N b}$ & $\mathbf{M n}$ & $\mathbf{S i}$ & $\mathbf{F e}$ & \\
\hline 5.2 & 22.0 & 1.8 & 7.0 & 0.4 & 0.4 & remainder & $57-62$ \\
\hline
\end{tabular}

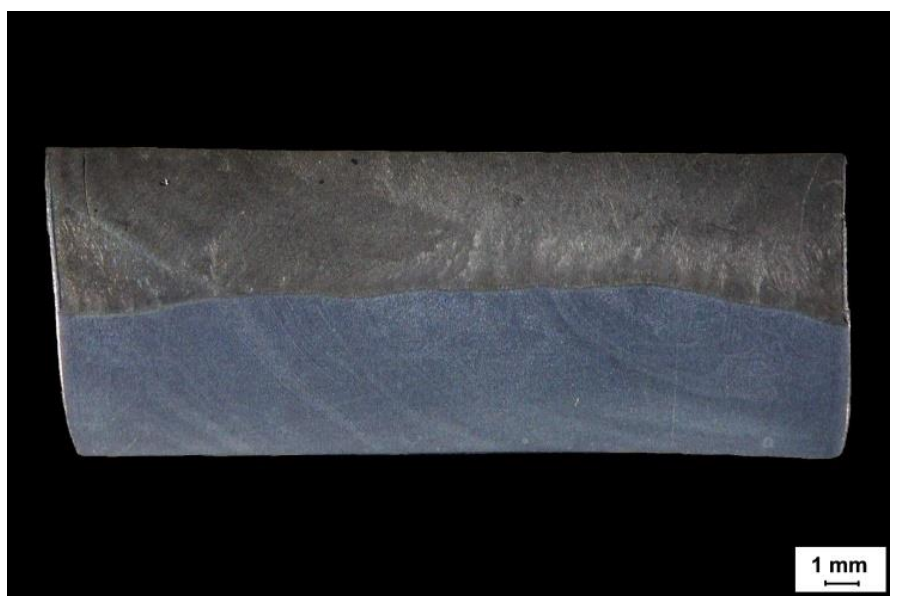

Figure 3. Macrostructure of a cross-section of CDP plate.

The deposited layer exhibits a very high abrasion resistance and has a standard thickness of 3-18 mm. Typical dimensions of abrasion plates are: $1000 \times 2000 \mathrm{~mm}, 1500 \times 3000 \mathrm{~mm}$, and $2000 \times$ $3000 \mathrm{~mm}$. It is possible to cut flat elements of any shape from abrasion plates and further shape them by bending and rolling. They are joined to the regenerated substrate with fillet welds, continuous or intermittent, depending on the type of abrasive plate load. The high content of carbon, chromium, and niobium allows for the obtainment of a structure similar to that of cast iron with the inclusion of very hard chromium borides, niobium carbides, and iron carbides. 


\subsection{Abrasion Resistant Layer Deposited by Covered ABRADUR 64 Electrode}

The abrasion-resistant layer was deposited by manual welding of an S335JR steel with a covered electrode, DIN 8555: E 10-UM-65-GR with a diameter of $5.0 \mathrm{~mm}$ and a welding current of $270 \mathrm{~A}$. The welding process was carried out using a buffer layer made with a covered electrode, ERWS 19-12-3 L with a diameter of $3.25 \mathrm{~mm}$ and a welding current of $110 \mathrm{~A}$, as shown in Figure 4. The purpose of the buffer layer was to transfer the stresses between the base material and hardfacing. The chemical composition and properties of the weld metal, ABRADUR 64 are given in Table 4.

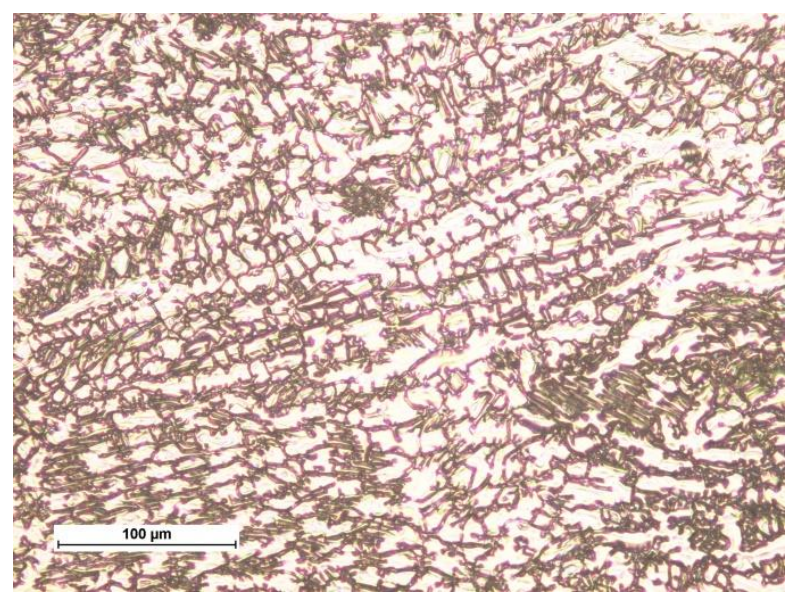

Figure 4. Microstructure of austenitic intermediate layer.

Table 4. Chemical composition and properties of the abrasion-resistant layer of ABRADUR 64-covered electrodes.

\begin{tabular}{ccccc}
\hline \multicolumn{4}{c}{ Chemical Composition, wt $\%$} & \multirow{2}{*}{ HRC } \\
\cline { 1 - 3 } $\mathrm{C}$ & $\mathrm{Cr}$ & $\mathrm{Nb}$ & $\mathrm{Fe}$ & \\
\hline 7.0 & 24.0 & 7.0 & remainder & 64 \\
\hline
\end{tabular}

\subsection{Abrasion Resistant Layer Formed by GMA with Ceramo-Metallic Wire}

The abrasion-resistant layer was made by single-layer GMA welding of 15 HM steel using a ceramo-metallic wire with a 50\% nickel carbide content of tungsten carbide (WC). The analysis of the chemical composition is shown in Table 5.

Table 5. Chemical composition of the layer formed by GMA (Gas Metal Active) with a ceramo-metallic wire layer.

\begin{tabular}{cccccc}
\hline \multicolumn{6}{c}{ Mass Percent of Elements in Abrasion Resistant, wt \% } \\
\hline Ni & C & Si & Cr & B & WC \\
\hline Remainder & 0.4 & 2.5 & 3.0 & 1.5 & 50 \\
\hline
\end{tabular}

\subsection{HARDOX 400 Steel Sheet}

HARDOX type steels are defined as "high-quality abrasion-resistant steels". This group of materials is derived from low-alloy steels destined for heat treatment and belongs to a new generation of machinable and weldable structural steels. Materials made of HARDOX steel are used where resistance to abrasion is required such as in the presence of variable loads, e.g., feeders, crushers, sieves, shafts, elements of incline lift, conveyors, blades, gears and chains, dumpers, loaders, trucks, motor-carriages, dozers, loading buckets, and screw conveyors. All types of HARDOX steel are delivered in the hardened condition (water-hardened). In the case of specifically required hardnesses, tempering is also performed. These steels can be bent, cut, drilled, machined, or turned under strictly 
defined conditions. HARDOX sheets can be machined using high-speed steel (HSS) or tools made of sintered carbides. The chemical composition and properties of HARDOX 400 steel are given in Table 6 .

Table 6. Chemical composition and mechanical properties of HARDOX 400.

\begin{tabular}{cccccc}
\hline \multicolumn{7}{c}{ Chemical Composition, wt \% } \\
\hline C & Mn & Mo & Cr & Si & Ni \\
\hline $0.14-0.32$ & 1.60 & $0.25-0.60$ & $0.30-1.40$ & 0.70 & $0.25-1.50$ \\
\hline \multicolumn{5}{c}{ Mechanical Properties } \\
\hline HBW & Tensile Strength (MPa) & Yield Strength (MPa) \\
\hline $370-430$ & \multicolumn{3}{c}{1250} & \multicolumn{2}{c}{1000} \\
\hline
\end{tabular}

\section{Results and Discussion}

\subsection{ASTM G65-00 Metal-Mineral Abrasion Resistance Test}

The tests of abrasive wear resistance for the selected materials were carried out in accordance with ASTM G 65-00. Procedure A, which is the most demanding examination of abrasion resistance, was used for the tests. During the test, the sample was mounted in a special fixture in which it was clamped to a rubber wheel $228.6 \mathrm{~mm}$ in diameter. The test sample was pressed against the rubber wheel with a force of $130 \mathrm{~N}$. Abrasive in the form of granular sand (gradation $250 \mu \mathrm{m}$ ) was delivered through the nozzle at the location of sample contact with the rubber wheel. The abrasive flow rate was 300-400 g/min. The wheel rotated in the direction corresponding to the abrasive flow, at a speed of $200 \mathrm{rpm}$ through 6000 revolutions. The tested samples were $25 \times 75 \times$ thickness of the sample, $\mathrm{mm}$, as shown in Figure 5. The mass loss was determined using an analytical balance precise to $0.0001 \mathrm{~g}$ (measurement accuracy up to 5 decimal places). To compare the results of abrasion resistance, the density of plates and abrasive layers was determined. As a measure of abrasion, the volume loss of the sample $\left(\mathrm{mm}^{3}\right)$ was determined, and is shown in Equation (1), Table 7, and Figure 6.

$$
\text { Volume loss }\left(\mathrm{mm}^{3}\right)=\text { mass loss }(\mathrm{g}): \operatorname{density}\left(\frac{\mathrm{g}}{\mathrm{cm}^{3}}\right) \times 1000
$$

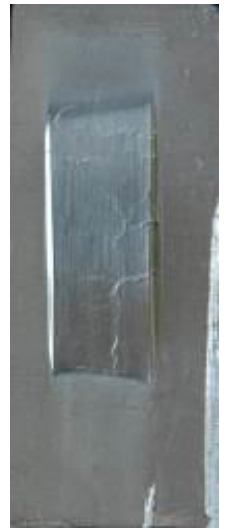

(a)

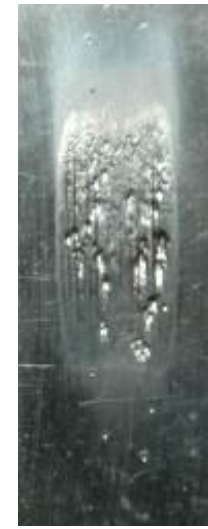

(b)

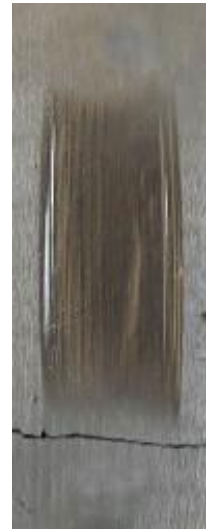

(c)

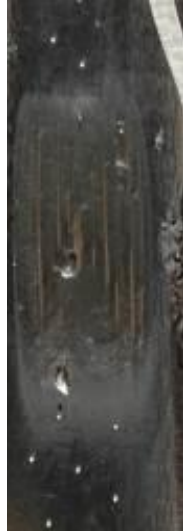

(d)

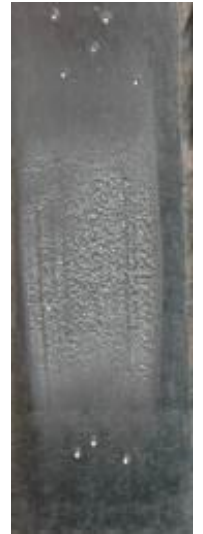

(e)

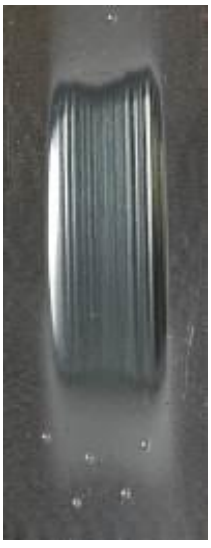

(f)

Figure 5. Abrasion tests samples following the abrasion test: (a) NANO; (b) ABRECOPLATE; (c) CDP; (d) ABRADUR 64; (e) WC; (f) HARDOX 400.

The tests have shown that the relative resistance to metal-to-metal abrasive wear of the nanocrystalline layer is 11 times higher when compared to the Hardox400 reference metal sheet. 
Table 7. ASTM G65-00 abrasion resistance test results.

\begin{tabular}{|c|c|c|c|c|c|c|c|}
\hline Material/Density $\left(\mathrm{g} / \mathrm{cm}^{3}\right)$ & Sample Number & $\begin{array}{c}\text { Sample Weight } \\
\text { before Test (g) }\end{array}$ & $\begin{array}{l}\text { Sample Weight } \\
\text { after Test (g) }\end{array}$ & Mass Loss (g) & $\begin{array}{l}\text { Average Mass } \\
\text { Loss (g) }\end{array}$ & $\begin{array}{l}\text { Average Volume } \\
\text { Loss }\left(\mathrm{mm}^{3}\right)\end{array}$ & $\begin{array}{l}\text { Relative Abrasion } \\
\text { Resistance * }\end{array}$ \\
\hline \multirow{2}{*}{ NANO/8.78 } & 1 & 102.9477 & 102.8393 & 0.1084 & \multirow{2}{*}{0.1113} & \multirow{2}{*}{12.6765} & \multirow{2}{*}{10.95} \\
\hline & 2 & 101.7964 & 101.6821 & 0.1143 & & & \\
\hline \multirow{2}{*}{ ABRECOPLATE/7.5961 } & 1 & 173.7335 & 173.6133 & 0.1202 & \multirow{2}{*}{0.11635} & \multirow{2}{*}{15.3170} & \multirow{2}{*}{9.07} \\
\hline & 2 & 173.6714 & 173.5589 & 0.1125 & & & \\
\hline \multirow{2}{*}{$\mathrm{CDP} / 7.1724$} & 1 & 128.6154 & 128.4378 & 0.1776 & \multirow{2}{*}{0.1697} & \multirow{2}{*}{23.3881} & \multirow{2}{*}{5.94} \\
\hline & 2 & 128.9438 & 128.7821 & 0.1617 & & & \\
\hline \multirow{2}{*}{ ABRADUR 64/7.1544 } & 1 & 136.2893 & 136.0933 & 0.1960 & \multirow{2}{*}{0.19825} & \multirow{2}{*}{27.7102} & \multirow{2}{*}{5.01} \\
\hline & 2 & 139.6675 & 139.4670 & 0.2005 & & & \\
\hline \multirow{2}{*}{ WC /10.6808 } & 1 & 179.6026 & 179.3009 & 0.3017 & \multirow{2}{*}{0.32360} & \multirow{2}{*}{30.2974} & \multirow{2}{*}{4.58} \\
\hline & 2 & 181.8750 & 181.5295 & 0.3455 & & & \\
\hline \multirow{2}{*}{ HARDOX 400/7.7115 } & 1 & 62.1029 & 61.0320 & 1.0709 & \multirow{2}{*}{1.0691} & \multirow{2}{*}{138.8705} & \multirow{2}{*}{1.00} \\
\hline & 2 & 62.5591 & 61.4918 & 1.0673 & & & \\
\hline
\end{tabular}

${ }^{*}$ Relative abrasion resistance compared to HARDOX 400. 


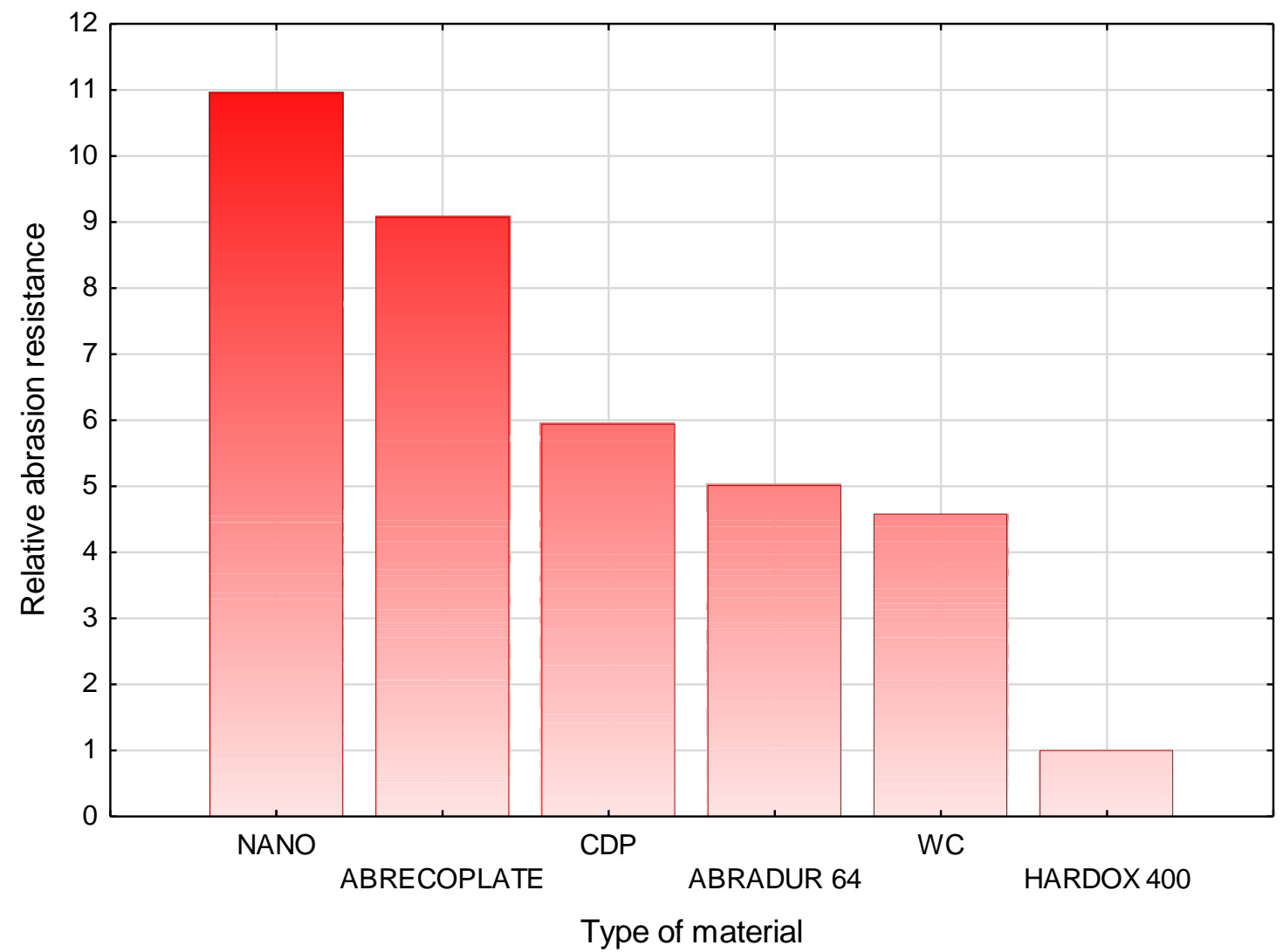

Figure 6. Comparison of the results of relative abrasive wear resistance of selected construction materials.

\subsection{Metallographic Testing}

The microscopic observations made it possible to determine the microscopic structure of the materials studied. The observations, carried out using a light microscope, did not show internal defects in the layers due to welding methods and material defects in the case of HARDOX 400 sheet, ABRECOPLATE, and CDP plates, Figure 7.

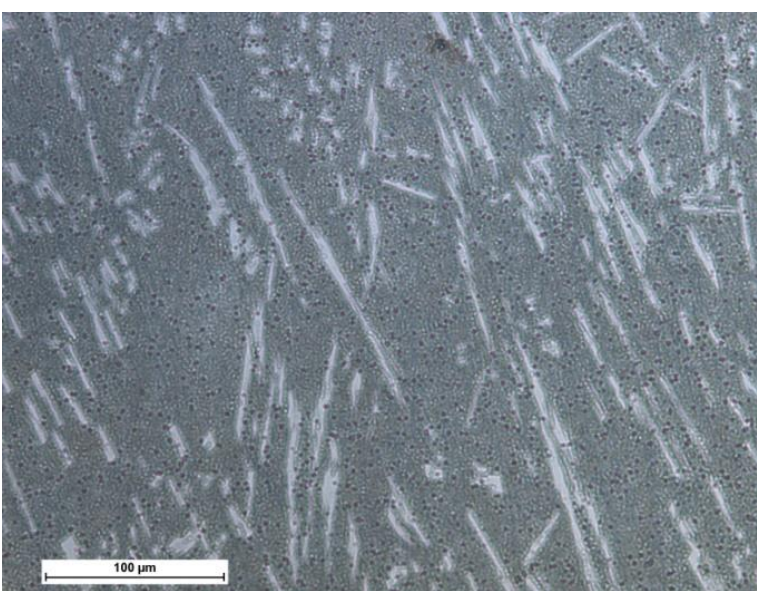

(a)

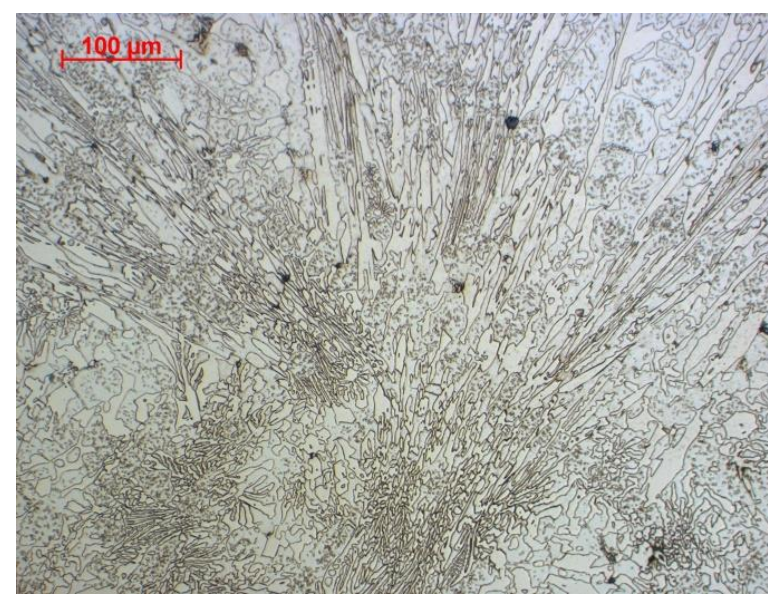

(b)

Figure 7. Cont. 


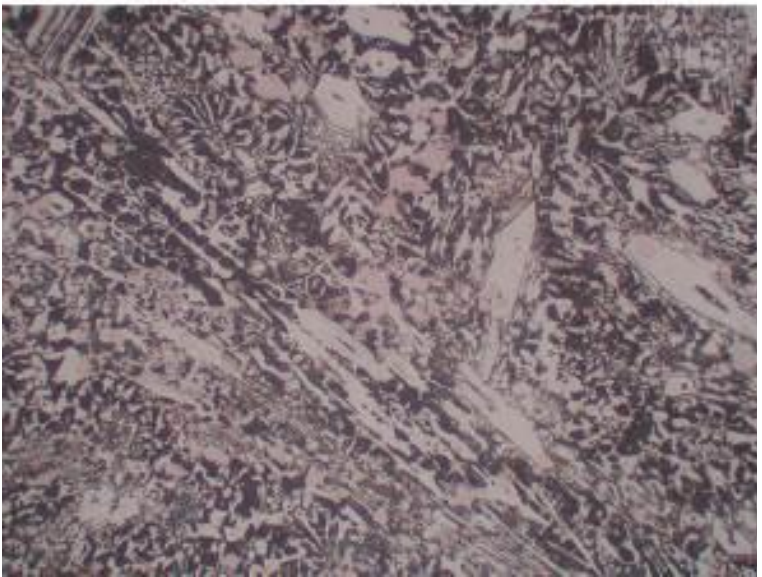

(c)

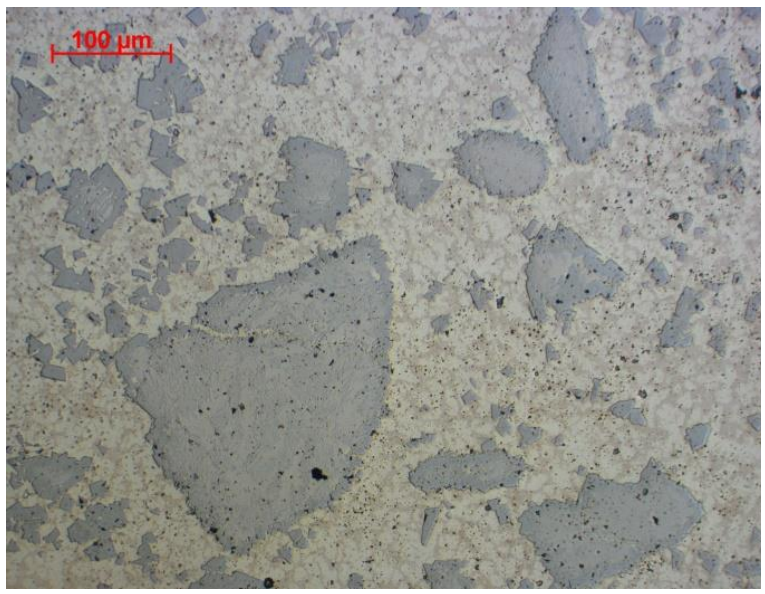

(e)

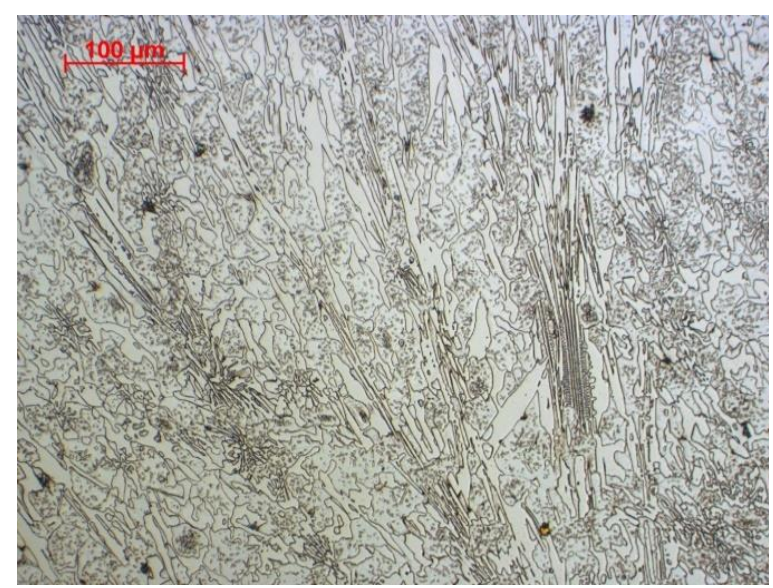

(d)

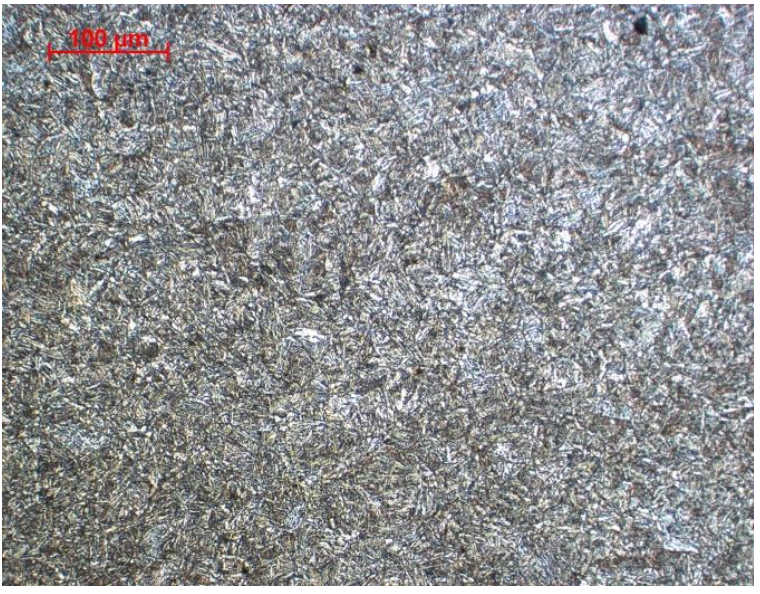

(f)

Figure 7. Microstructure of layers resistant to abrasive wear. (a) NANO; (b) ABRECOPLATE; (c) CDP; (d) ABRADUR 64; (e) WC; (f) HARDOX 400; Reagents selected for abrasion resistant material.

Metallographic examinations carried out on a scanning microscope technique (SE) revealed large amounts of primary carbide precipitates highly dispersed in the zone of the nanocrystalline matrix, as shown in Figures 8 and 9.

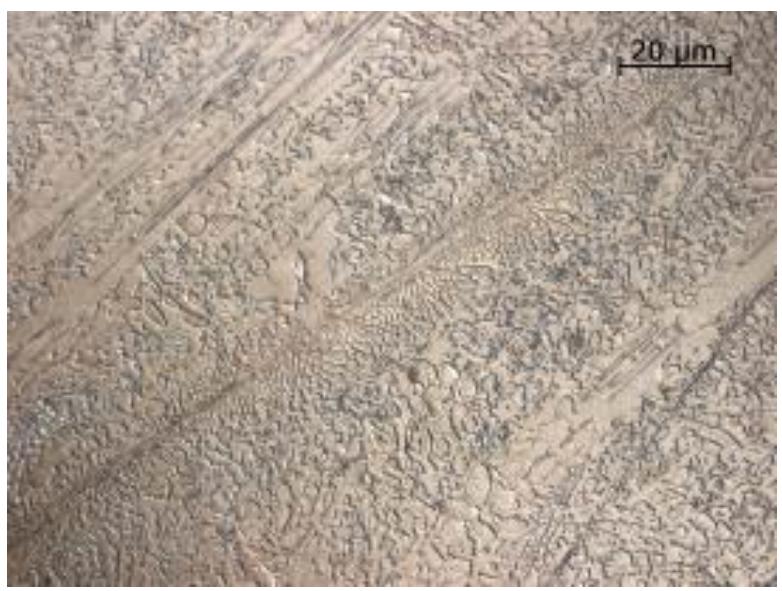

Figure 8. Microstructure of a nanocrystalline layer with eutectic like carbides of NANO (Fe-Cr-Nb-B). 


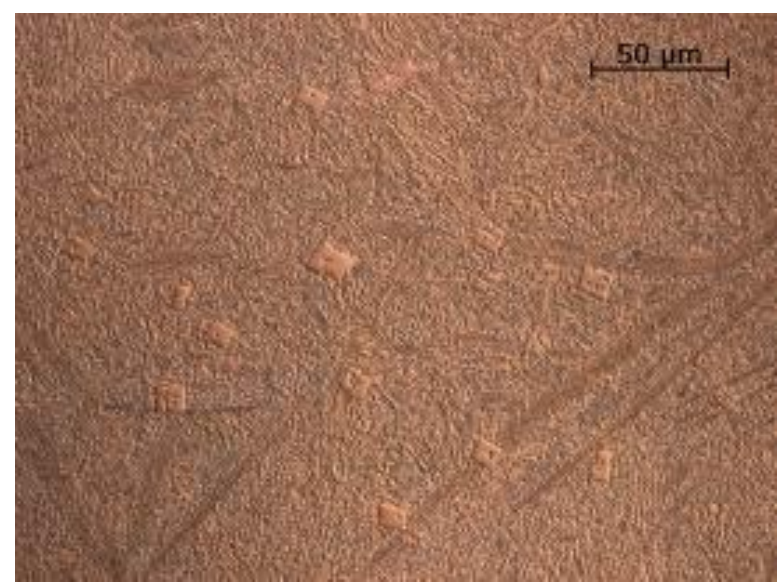

Figure 9. Microstructure of a nanocrystalline layer with carbide precipitates of NANO (Fe-Cr-Nb-B).

SEM analysis showed that the observed carbide precipitates which appeared larger in size were niobium and chromium carbides, shown in Figures 10 and 11.

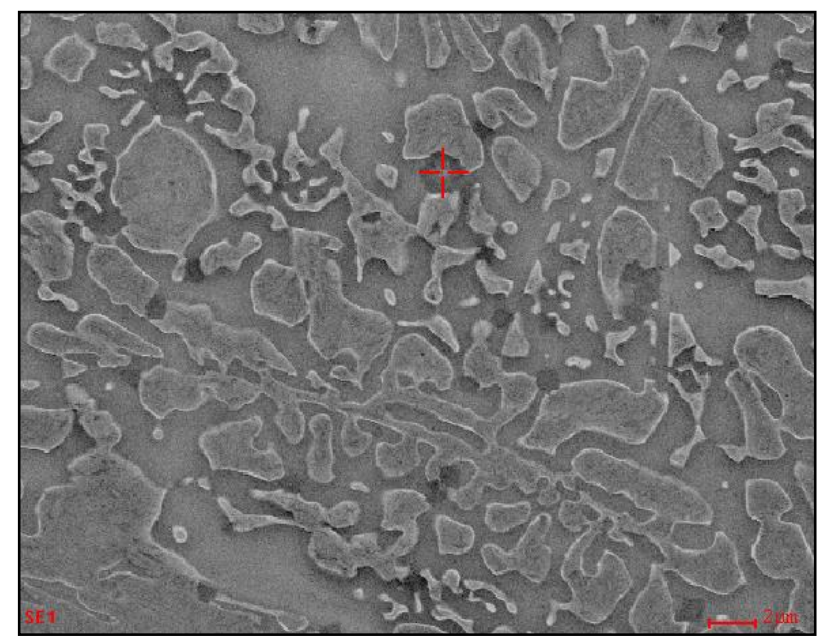

(a)

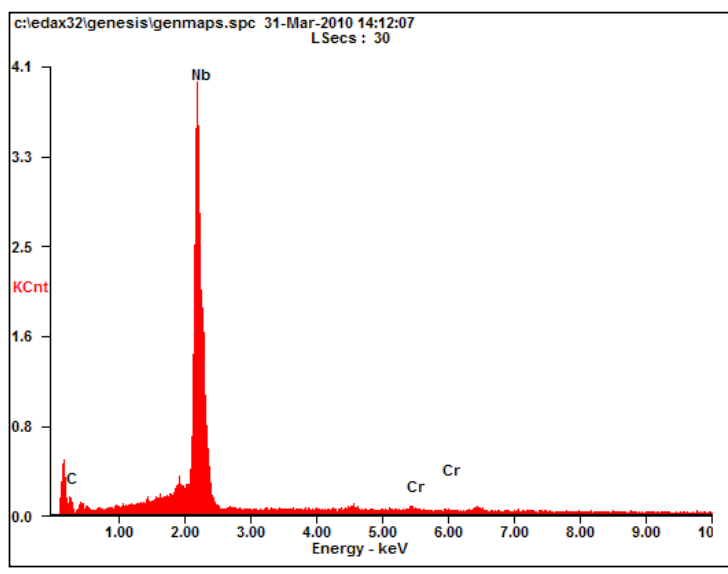

\begin{tabular}{ccc}
\hline Element & Wt (\%) & At $(\%)$ \\
\hline $\mathrm{CK}$ & 32.90 & 75.36 \\
$\mathrm{AlK}$ & 00.99 & 1.01 \\
$\mathrm{NbL}$ & 57.52 & 17.84 \\
$\mathrm{CrK}$ & 1.99 & 1.05 \\
FeK & 7.60 & 3.74 \\
Matrix & Correction & ZAF \\
\hline
\end{tabular}

(b)

Figure 10. (a) SEM image of the nanostructural layered microstructure over the EDS analysis area-a precipitation of niobium carbide; (b) the EDS spectrum with the above indicated spot-separation of niobium carbide and results of the quantitative elemental analysis. 


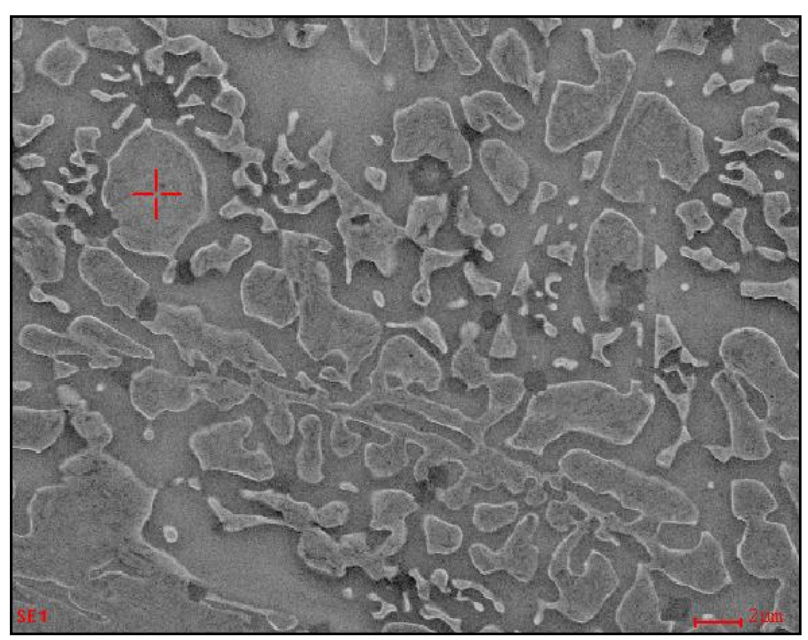

(a)

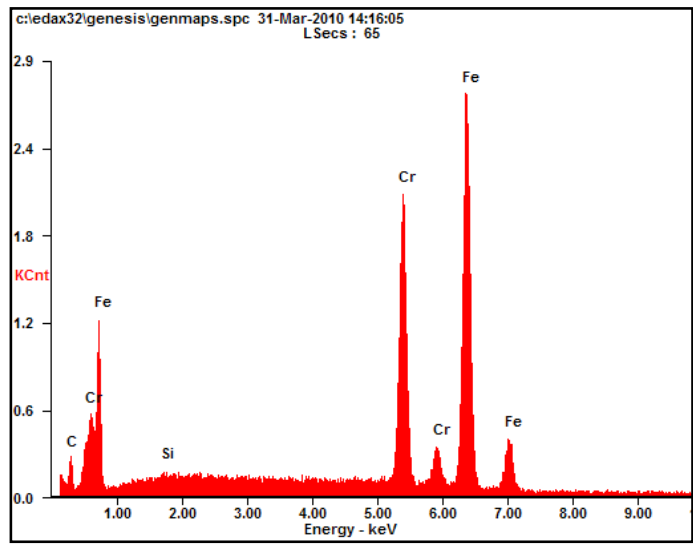

\begin{tabular}{ccc}
\hline Element & Wt (\%) & At (\%) \\
\hline CK & 19.22 & 52.00 \\
SiK & 1.28 & 1.48 \\
CrK & 25.98 & 23.74 \\
MnK & 1.22 & 0.72 \\
FeK & 52.30 & 32.06 \\
Matrix & Correction & ZAF \\
\hline
\end{tabular}

(b)

Figure 11. (a) SEM image of the nanostructural layer microstructure over the EDS analysis area-a precipitation of chromium carbide; (b) the EDS spectrum showing the above indicated spot-separation of chromium carbide and results of the quantitative elemental analysis.

The size of the crystallographic grains of the $\mathrm{Fe}-\mathrm{Cr}-\mathrm{Nb}-\mathrm{B}$ nanocrystalline microstructure was measured using an Xpert PRO X-ray diffractometer by PANalytical and a computerized radiation recording system equipped with a cobalt lamp at $40 \mathrm{kV}$ and $30 \mathrm{~mA}$ current with a strip detector, in the Bragg angle range of $30-120^{\circ}$. Based on calculations of crystalline sizes carried out using the Scherrer Equation (2), it was found that the average grain size of the layered microstructure measured in the direction perpendicular to the deposited substrate was approximately $20 \mathrm{~nm}$.

$$
D=\frac{K \cdot \lambda}{B_{\text {struct }} \cdot \cos \theta}
$$

where: $D$-the average size of the crystallite in the direction perpendicular to the planes of deflection; $K$-Scherrer constant $(0.98) ; \lambda$-wavelength; $B_{\text {struct }}$-width of reflexes; $\theta$-the angle of reflection.

Analysis of the diffraction pattern of the nanocrystalline layers of $\mathrm{Fe}-\mathrm{Cr}-\mathrm{Nb}-\mathrm{B}$ showed the presence of reflections from the three types of carbides (Figure 12):

- $\quad \mathrm{Cr}_{7} \mathrm{C}_{3}$ from the lattice plane (002), (151), (321), (202), (222), (260), (081);

- $\quad \mathrm{Cr}_{23} \mathrm{C}_{6}$ from the lattice plane (400), (420), (422), (333), (440), (531), (620), (911);

- $\quad \mathrm{NbC}$ from the lattice plane (111), (200), (220). 


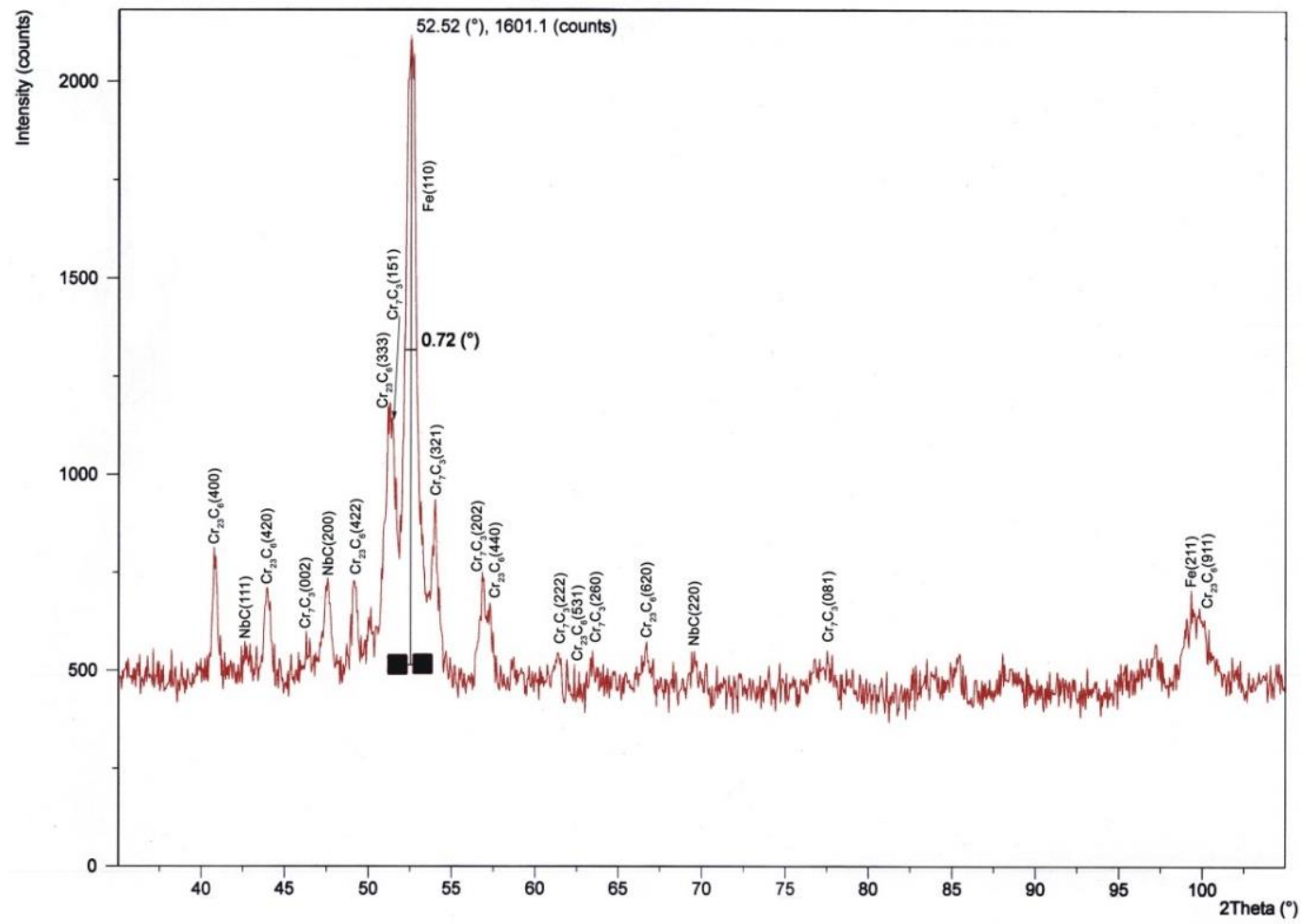

Figure 12. The diffraction pattern of the nanocrystalline $\mathrm{Fe}-\mathrm{Cr}-\mathrm{Nb}-\mathrm{B}$ layer.

\subsection{Hardness Testing}

In order to determine the hardness of the tested materials, the Rockwell hardness measurement was carried out in five places on the weld face/sheet surface and in four locations on the deposit weld/sheet cross-section using the Vickers method at a load of $1000 \mathrm{~g}$, shown in Figures 13 and 14. Hardness measurement results are shown in Table 8 and Figure 15.

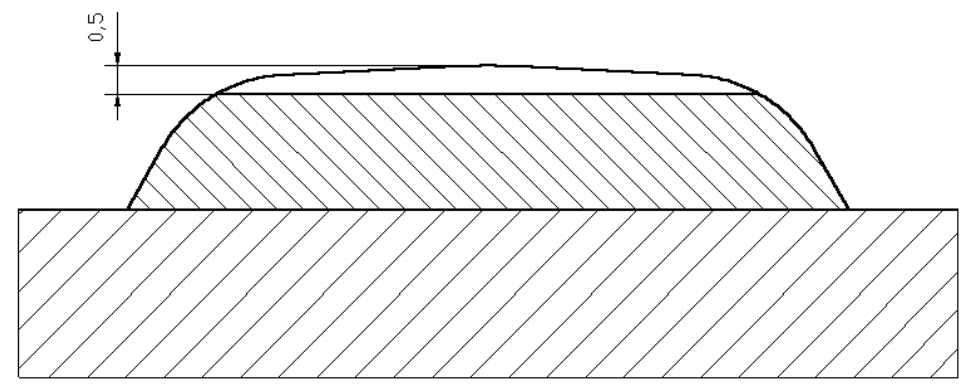

Figure 13. Preparation for hardness testing.

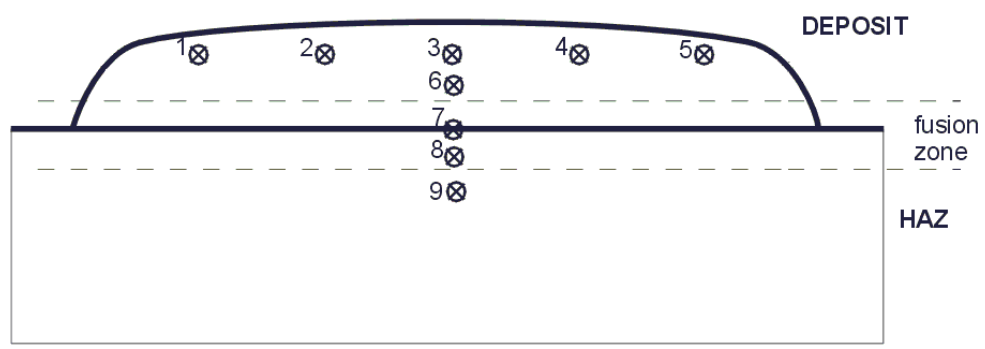

Figure 14. Hardness test area. 


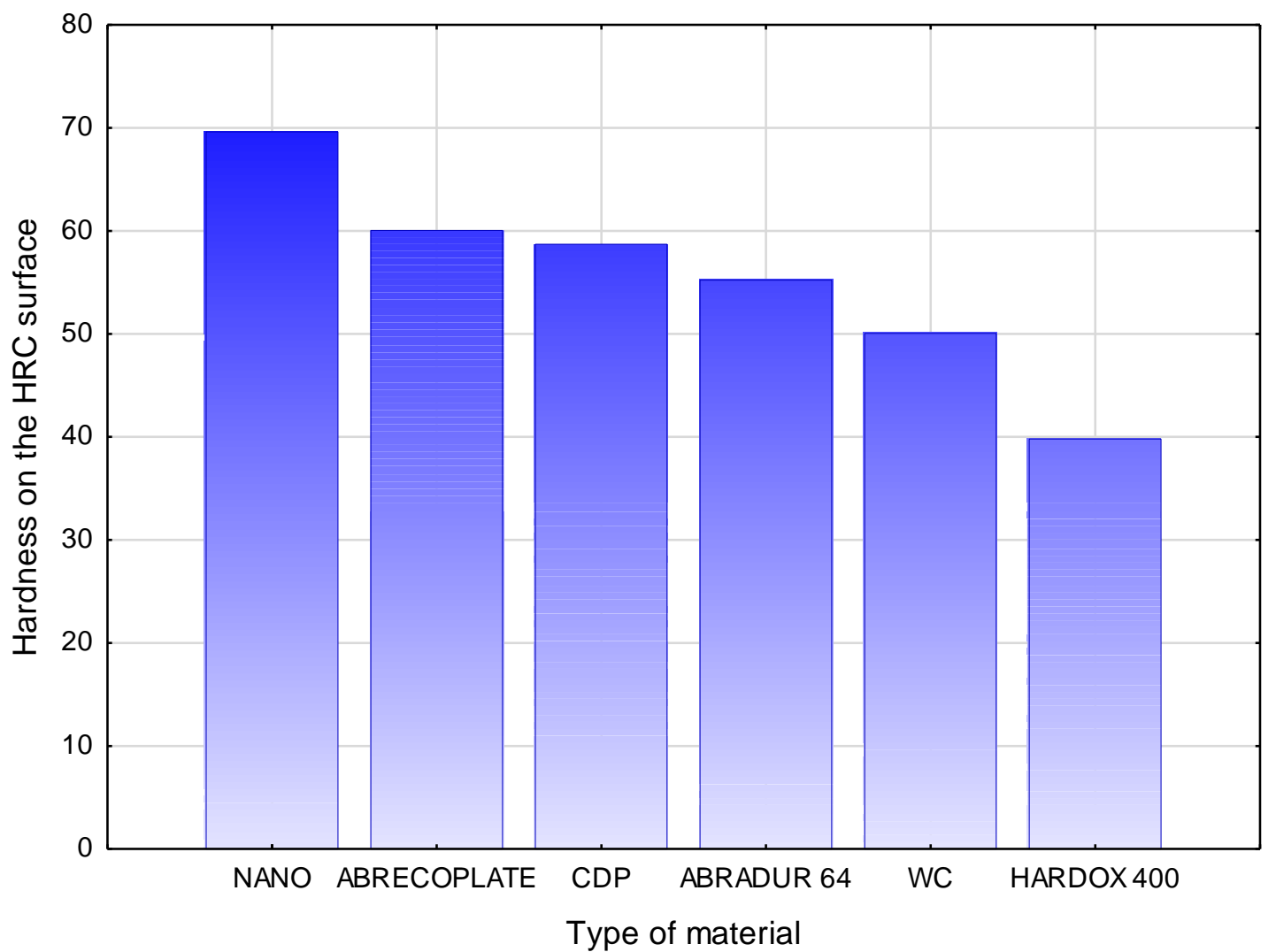

Figure 15. Average hardness of the surface of tested construction materials.

Table 8. Hardness testing results on the face and cross-section of deposit welds and sheets.

\begin{tabular}{ccccccccccc}
\hline \multirow{2}{*}{ Material } & \multicolumn{1}{c}{ HRC } & \multicolumn{4}{c}{ HV 1 } \\
\cline { 2 - 11 } & $\mathbf{1}$ & $\mathbf{2}$ & $\mathbf{3}$ & $\mathbf{4}$ & $\mathbf{5}$ & Average & $\mathbf{6}$ & $\mathbf{7}$ & $\mathbf{8}$ & $\mathbf{9}$ \\
\hline NANO & 69 & 70 & 69 & 71 & 69 & 69.60 & 679 & 289 & 179 & 188 \\
ABRECOPLATE & 60 & 58 & 61 & 61 & 62 & 60.04 & 663 & 154 & 148 & 106 \\
CDP & 62 & 59 & 58 & 61 & 58 & 58.70 & 643 & 299 & 179 & 182 \\
ABRADUR 64 & 57 & 56 & 57 & 54 & 52 & 55.20 & 556 & 174 & 304 & 290 \\
WC & 54 & 50 & 48 & 51 & 49 & 50.04 & 563 & 486 & 180 & 167 \\
HARDOX 400 & 41 & 40 & 39 & 40 & 39 & 39.80 & 380 & 378 & 377 & 378 \\
\hline
\end{tabular}

\section{Conclusions}

The metallographic examinations of the materials selected for the tests did not show any internal or external defects in the layers formed by MMA welding with coated electrodes and GMA welding. Analysis of the test results of the obtained layers of arc-welded Fe-Cr-Nb-B-type alloy confirmed:

- The obtained layers are made of crystallites with a size of $20 \mathrm{~nm}$, which classifies these layers as nanocrystalline.

- $\quad$ Numerous carbide precipitates with empirical formula $\mathrm{Cr}_{7} \mathrm{C}_{3}, \mathrm{Cr}_{23} \mathrm{C}_{6}$, and $\mathrm{NbC}$ were observed and detected in the samples.

The ABRECOPLATE plate has a structure of white cast iron with chromium-molybdenum carbide precipitates. To join this plate with a low-carbon steel support plate, a soft binder was used on the copper matrix, which perfectly transfers the stresses occurring between the layers. In the case of CDP, the surface layer structure is a chromium cast iron containing many primary carbides.

The layer created with ABDADUR 64 coated electrodes possesses a eutectic iron structure with numerous precipitates of niobium and chromium carbides. The use of an austenitic steel buffer layer, in 
this case, allowed for crack avoidance that could propagate through to the substrate material. The layer formed by GMA surfacing with a ceramo-metallic wire is characterized by a nickel matrix containing many tungsten carbides. As a result of the thermal cycle, it can be observed that the WC carbides are partially dissolved, which may reduce the abrasion resistance of such layers.

HARDOX 400 is characterized by a tempered martensite structure. The hardness measurements carried out on the ground face of abrasion-resistant layers showed that all materials have a hardness similar to the hardness quoted by the manufacturers. The highest hardness on the surface is characterized by the nanocrystalline layer, with a hardness of 70 HRC. The tests of resistance to abrasive wear of the metal-mineral type, according to ASTM G 65-00, have shown that the best usable properties are characterized by a layer made of Fe-Cr- $\mathrm{Nb}-\mathrm{B}$ alloy. The metal-mineral abrasion resistance of this material is 11 times higher than a typical HARDOX 400 abrasion-resistant sheet.

Author Contributions: Conceptualization, J.G. and A.C.; Methodology, M.A.; Validation, A.K., M.Ż.; Formal Analysis, J.G. and A.C.; Investigation, M.A. and M.Ż.; Writing-Original Draft Preparation, J.G.; Writing-Review \& Editing, A.K.

Funding: The publication was co-financed from the statutory subsidy of the Faculty of Mechanical Engineering of the Silesian University of Technology in 2018.

Conflicts of Interest: The authors declare no conflicts of interest.

\section{References}

1. Kato, K. Abrosive wear of metals. Tribol. Int. 1997, 5, 333-338. [CrossRef]

2. Grigoroudis, K.; Stephenson, D.J. Modelling low stress abrasive wear. Wear 1997, 213, 103-111. [CrossRef]

3. Zum Gahr, K.H. Wear by hard particles. Tribol. Int. 1998, 10, 587-596. [CrossRef]

4. Sundararajan, G.; Manisz, R. Solod particle erosion behaviour of metallic materiałs at room and elevated temperatures. Tribol. Int. 1997, 30, 339-359. [CrossRef]

5. Ma, X.; Liu, R.; Li, D.Y. Abrasive wear behavior of D2 tool steel with respect to load and sliding speed under dry sand/rubber wheel abrasion condition. Wear 2000, 241, 79-85. [CrossRef]

6. Masen, M.A.; de Rooij, M.B.; Schipper, D.J. Micro-contact based modelling of abrasive wear. Wear 2005, 241, 75-89. [CrossRef]

7. Stachowiak, G.W. Particle angularity and its relationship to abrasive and erosive wear. Wear 2000, 241, 214-219. [CrossRef]

8. Mbabazi, J.G.; Sheer, T.J.; Schandu, R. A model predict erozion on mild steel surfaces impacted by boiler fly ash particles. Wear 2005, 257, 612-624. [CrossRef]

9. Górka, J.; Czupryński, A. Testing of flame sprayed $\mathrm{ZrO}_{2}$ matrix coatings containing CaO. Appl. Mech. Mater. 2015, 809-810, 501-506. [CrossRef]

10. Włosiński, W.; Chmielewski, T. Plasma-hardfaced chromium protective coatings-effect of ceramic reinforcement on their wettability by glass. In Contributions of Surface Engineering to Modern Manufacturing and Remanufacturing 3rd International Conference on Surface Engineering; Southwest Jiaotong University Press: Chengdu, China, 2002; pp. 48-53.

11. Czupryński, A.; Górka, J.; Adamiak, M.; Tomiczek, B. Testing of Flame Sprayed $\mathrm{Al}_{2} \mathrm{O}_{3}$ Matrix Coatings Containing $\mathrm{TiO}_{2}$. Arch. Metall. Mater. 2016, 61, 1017-1023. [CrossRef]

12. Boncel, S.; Górka, J.; Shaffer, M.S.P.; Koziol, K. Shear-induced crystallisation of molten isotactic polypropylene within the intertube channels of aligned multi-wall carbon nanotube arrays towards structurally controlled composites. Mater. Lett. 2014, 116, 53-56. [CrossRef]

13. Chmielewski, T.; Golański, D.; Włosiński, W.; Zimmerman, J. Utilizing the energy of kinetic friction for the metallization of ceramics. Bull. Pol. Acad. Sci. Tech. Sci. 2015, 63, 201-207. [CrossRef]

14. Reisgen, U.; Stein, L.; Balashov, B.; Geffers, C. Nanophase hardfaced coatings. In Materialwissenschaft und Werkstofftechnik; Springer: Berlin, Germany, 2008; Volume 39, pp. 791-794.

15. Czupryński, A.; Górka, J.; Adamiak, M. Examining properties of arc sprayed nanostructured coatings. Metalurgija 2016, 55, 173-176.

16. Lisiecki, A. Titanium matrix composite Ti/TiN produced by diode laser gas nitriding. Metals 2015, 5, 54-69. [CrossRef] 
17. Adamiak, M.; Tomiczek, B.; Górka, J.; Czupryński, A. Joining of the AMC composites reinforced with $\mathrm{Ti}_{3} \mathrm{Al}$ intermetallic particles by resistance butt welding. Arch. Metall. Mater. 2016, 61, 847-851. [CrossRef]

18. Janicki, D. Disk laser welding of armor steel. Arch. Metall. Mater. 2014, 59, 1641-1646. [CrossRef]

19. Burdzik, R.; Konieczny, Ł.; Stanik, Z.; Folega, P.; Smalcerz, A.; Lisiecki, A. Analysis of impact of chosen parameters on the wear of camshaft. Arch. Metall. Mater. 2014, 59, 957-963. [CrossRef]

20. Grajcar, A.; Różański, M.; Stano, S.; Kowalski, A. Microstructure characterization of laser-welded Nb-microalloyed silicon-aluminum TRIP steel. J. Mater. Eng. Perform. 2014, 23, 3400-3406. [CrossRef]

21. Chmielewski, T.; Golański, D.; Włosiński, W. Metallization of ceramic materials based on the kinetic energy of detonation waves. Bull. Pol. Acad. Sci. Tech. Sci. 2015, 63, 449-456. [CrossRef]

22. Janicki, D. High power diode laser cladding of wear resistant metal matrix composite coatings. In Solid State Phenomena, Mechatronic Systems and Materials; Trans Tech Publications: Zürich, Switzerland, 2013; Volume 199, pp. 587-592.

23. Chmielewski, T.; Golanski, A. New method of in-situ fabrication of protective coatings based on Fe-Al intermetallic compounds. Proc. Inst. Mech. Eng. Part B J. Eng. 2011, 225, 611-616. [CrossRef]

24. Golański, D.; Dymny, G.; Kujawińska, M.; Chmielewski, T. Experimental investigation of displacement/strain fields in metal coatings deposited on ceramic substrates by thermal spraying. In Solid State Phenomena; Trans Tech Publications: Zürich, Switzerland, 2015; Volume 240, pp. 174-182.

25. Poole, C.P., Jr.; Ownes, F.J. Introduction to Nanotechnology; Wiley: Hoboken, NJ, USA, 2003; pp. 1-8.

26. Boncel, S.; Górka, J.; Shaffer, M.S.P.; Koziol, K. 'Binary salt' of hexane-1,6-diaminium adipate and 'carbon nanotubate' as a synthetic precursor of carbon nanotube/Nylon-6,6 hybrid materials. Polym. Compos. 2014, 35, 523-529. [CrossRef]

27. Heath, G. Nanotechnology and welding-Actual and possible future applications. In Proceedings of the Castolin-Eutectic Seminar, Brussels, Belgium, 25 October 2006; pp. 15-19.

28. Sevostianov, I.; Kachanov, M. Effect of interphase layers on the overall elastic and conductive properties of matrix composites. Applications to Nanosize inclusion. Int. J. Solids Struct. 2007, 44, 1304-1315. [CrossRef]

29. Wagner, D.; Vaia, R. Nanocomposites: Issues at the Interface. Mater. Today 2004, 7, 38-42. [CrossRef]

30. Yao, J.; Zhang, Q.; Gao, M.; Zhang, M. Microstructure and wear property of carbon nanotube carburizing carbon steel by laser surface remelting. Appl. Surf. Sci. 2008, 254, 7092-7097. [CrossRef]

31. Laha, T.; Kuchibhatla, S.; Seal, S.; Li, W.; Agarwal, A. Interfacial phenomena in thermally sprayed multiwalled carbon nanotube reinforced aluminum nanocomposite. Acta Mater. 2007, 55, 1059-1066. [CrossRef]

32. Esawi, A.; Farag, M. Carbon nanotube reinforced composites: Potential and current challenges. Mater. Des. 2007, 28, 2394-2401. [CrossRef]

33. Chen, W.X.; Tu, J.P.; Wang, L.Y.; Gan, H.Y.; Xu, Z.D.; Zhang, X.B. Tribological application of carbon nanotubes in a metal-based composite coating and composites. Carbon 2003, 41, 215-222. [CrossRef] 